\title{
THE INFLUENCE OF SOCIAL MEDIA ON PALESTINIAN SECONDARY SCHOOLS ENGLISH WRITING SKILLS FROM ENGLISH TEACHERS' PERSPECTIVES IN JENIN REGION
}

\author{
Tahani R. K. Bsharat ${ }^{1}$ \\ 1Faculty of Major Language Studies. Universiti Sains Islam Malaysia, Malaysia \\ (tahanibsharat@raudah.usim.edu.my) \\ Fariza Behak ${ }^{2}$ \\ ${ }^{2}$ Senior Lecturer, Faculty of Major Language Studies, Universiti Sains Islam Malaysia, Malaysia, \\ (fariza@usim.edu.my)
}

\begin{abstract}
Writing skills play a crucial role in this modern world, and one must develop these skills to excel in teaching-learning processes. Therefore, writing becomes one of the most important abilities of all four language skills to communicate effectively in this global environment. Since English is commonly used throughout the world, learners need to acquire their writing skills to be effective in their respective fields. The teachers have to consider and seek to incorporate different teaching methods, especially social media, during these challenging times with the presence of COVID 19. This study aimed to find out the influence of social media on Palestinian secondary schools' English writing skills from teachers' perspectives in the Jenin region, and also the influence of (gender, academic qualification, and years of experience) variables in the influence of social media on Palestinian secondary school's English writing skills from teachers' perspectives in the Jenin region. The study sample consists of (30) Palestinian secondary schools English language teachers who will select randomly in the scholastic year (20192020). Thus, the researcher adopted the descriptive-analytic approach (quantitative method). The results show that a negative influence of social media on Palestinian secondary schools students' English writing skills.
\end{abstract}

Keywords: Writing Skills; Social Media; Secondary Students

First Received:

(January 15, 2021)
Final Proof Received:

(March 31, 2021)

\section{INTRODUCTION}

Using social media tools in teaching sometimes can be very challenging for teachers. Students can be a very good consulting source because they are the experts, and they have a better understanding of the tools. Crook et al., (2008) added that Social media tools provide learners with new opportunities to become independent in their study and research.

Writing is one of the other fourth language skills that require special attention, as it is a productive language process. It is the process of transforming thoughts and ideas into written communication. As Millrood, (2001) defined writing as a communicative skill to send, store and retrieve messages with the help of written symbols. Writing can be expressive, poetic, informative, and persuasive. Depending on the type of writing, the 
writer concentrates either on the written piece's subject matter, the reader, or one's feelings and thoughts. Writing is an important language activity and a major classroom procedure. It is important to provide evidence of our students' achievements.

Besides, teachers were afraid of losing class influence (Minocha, 2009; Sobaih, Moustafa, Ghandforoush, \& Khan, 2016). They also felt that students belong to social media and shouldn't intervene (Dickie \& Meier, 2015). Students' attitudes were often seen as troublesome (Goktalay, 2013), or teachers were afraid that less technically qualified students would stay behind (Minocha, 2009). Social media has also been argued to be best adapted for subjects such as languages (Margaryan \& Littlejohn, 2011). Finally, there have been reports of enthusiasm (Kamalodeen \& Jameson-Charles, 2016) and the ability to put effort into learning how to use social media in class (Kukulska-Hulme, 2012), as well as resistance to change much an obstacle as an expression of high expectations about social media's contribution to education (Van den beemt, Thurlings, \& Willems, 2019).

Writing skills play a great role in conveying a written message accurately. It is equated with speech because both are used to convey ideas, notions, and information. Kavaliauskienè, (2010) added the most common applications of e-learning include weblogs and social media, which serve as valuable tools for improving writing skills in a foreign language. Their advantages in language classes include instant publishing online, leadership, and an online portfolio of student written work. Solis (2008) comprised the activities of social media that involve socializing and networking online through words, pictures and videos.

Writing for training is another purpose for teaching writing. Writing used for the purpose of training initially presents students with patterns of linguistic and rhetorical forms that might be new to them. Students are given practice in using and manipulating these new patterns. When students do this kind of writing, they work with units of discourse longer than the sentence. The training aims to manipulate rhetorical and grammatical structures, especially through use or transformations. The researcher believes that the need for the study springs from the following resources. Firstly, the researcher interviews English supervisors and teachers who have a wide background about students' levels and results, especially in the secondary exams. Most of them agree with the idea that students suffer from weak main writing skills. Secondly, this field's lack of research takes our teachers and students far away from technology contemporary life. So, the new tendency in English language education focuses on integrating technology into the teaching and learning process and improving EFL collaborative writing skills.

\section{LITERATURE REVIEW}

According to (Millrood, 2001: 147) discussed a three-phase framework of teaching to write. First is pre-writing schemata. This phase is started by identifying a person who already has activation, motivation for writing, preparation for the writing, and 
familiarization with the text format. Second is while-writing, it is thesis development, writing from notes, proceeding from a given beginning phrase, and following a plan. The third is post-writing. This phase involves reflection on spelling and grammar errors, sharing the writing with other students-redrafting, peer editing. The researcher found the importance of using English writing skills in teaching and learning in general, and the internet has been praised as an instructional tool.

According to (Khalil, 2002: 133-135), teaching and learning writing is crucial for both teachers and learners. He found that foreign speakers of English face problems and made mistakes in punctuation, especially in sentence forming, usage, and mechanics of writing. The researcher found the crucial strategies of using English writing skills in teaching and learning process. How the technology is used and how it is integrated into the learning process is important. Zepke \& Leach, 2010) suggested that motivation and student dispositions will influence their ability to engage in interactive learning, where the line between online learning and socialization is blurred.

Al-Sharawneh (2014) said that the skills of the writing skill of language teachers and students have always been important because the results of such an influence are used for a variety of administrative, instructional and research purposes. Classroom teachers benefit from these results. They use these results to help improve, influence, refine and shape their students' attained writing ability. He added that the assessment of the writing ability among language teachers and students has always been important because the results of such an evaluation are used for a variety of administrative, instructional, and research purposes. Classroom teachers benefit from these results. They use these results to help improve, influence, refine and shape their students' attained writing ability.

The researcher found the benefits of using the assessment of teaching English writing skills and its importance learning process. According to Toivo (2012), social media is a new information network and information technology using a form of communication utilizing interactive and user-produced content, and interpersonal relationships are created and maintained. Typical social media network services could be content sharing, web communities, and Internet forums. The researcher found that the students have to keep the channel of communication open through their own efforts and ensure both the choice of sentence structure and how our sentences are linked together and sequenced. So, the produced text can be interpreted on its own.

With regard to the cognitive problem, students learn to write through a process of instructions. To do so, students have to master the written form of the language and learn the writing structures, which are not used in speaking.

Students also have to learn how to organize their ideas so a reader can absorb them without being present or recognizing the writer. The influence of educational uses of social media on motivation has been explored in several studies. Many of these studies have shown that social media, especially Facebook and Twitter, has increased students' 
motivation and participation (e.g. Cole, Hibbert, \& Kehoe, 2013; Rinaldo, Tapp, \& Laverie, 2011; Wang, 2013). The more students use Facebook, the more they believe like they are part of their class (Dougherty \& Andercheck, 2014). In addition, the number of tweets sent was found to positively correlate with student engagement (Evans, 2014; Menkhoff, Chay, Bengtsson, Woodard, \& Gan, 2015).

A significant consequence is the use of social media, and Facebook in particular, to write lessons and language courses. Studies based on writing and language have shown increased student outcomes and engagement by using social media as learning resources (Lee, Koo, \& Kim, 2016; Suthiwartnarueput \& Wasanasomsithi, 2012; Van den beemt et al., 2019; Vikneswaran \& Krish, 2016).

The current study may resemble the previous studies in the use of social media as the data. Nevertheless, this study's contexts are different from the above contexts, in terms of concentrating on writing skills and during this difficult time for the whole world because spreading of COVID -19 or Coronavirus. The purpose of this study is to explore the influence of implementing social media on Palestinian secondary schools' progress in writing skills and their attitudes towards writing from teachers' perspectives at schools in the Jenin region and recognize whether social media affects the students writing competence positively or negatively during the scholastic year 2019-2020.

\section{METHOD}

The researcher adopted the descriptive-analytic approach because it is suitability to the nature of the study and the influence of social media on Palestinian secondary schools' English writing skills from teachers' perspectives in the Jenin region. To achieve these goals, the researcher designs a questionnaire.

\section{The Sample of the Study}

The sample consists of (30) Palestinian secondary schools' English language teachers who select randomly in the scholastic year (2019-2020). Tables (1), (2), and (3) show the distribution of the sample of the study depending on its independent variables.

Table 1.

Sample Distribution According to the Gender variable.

\begin{tabular}{lll}
\hline Gender & Frequency & Percentage (\%) \\
\hline Female & 20 & 66.7 \\
Male & 10 & 33,3 \\
\hline Total & 30 & 100 \\
\hline
\end{tabular}


Table 2.

Sample Distribution According to the Academic Qualification variable.

\begin{tabular}{lll}
\hline Experience & Frequency & Percentage (\%) \\
\hline Bachelor or less & 26 & 68,7 \\
Master or more & 4 & 31,3 \\
\hline Total & 30 & 100 \\
\hline
\end{tabular}

Table 3.

Sample Distribution According to the Years of Experience variable.

\begin{tabular}{lll}
\hline Experience & Frequency & Percentage (\%) \\
\hline 5 years or less & 3 & 10 \\
More than 5 years & 27 & 90 \\
\hline Total & 30 & 100 \\
\hline
\end{tabular}

\section{Instruments}

Depending on the related studies, literature review, and experts' consultation, the researchers designed a questionnaire to examine the influence of social media on Palestinian secondary schools' English writing skills from teachers' perspectives in the Jenin region. The questionnaire consists of two sections. Section one consists of personal information like gender, academic qualification, and years of experience.

The questionnaire consists of (24) items divided into (4) domains, as shown in table (4).

Table 4.

The items of the questionnaire According to the study Domains.

\begin{tabular}{llll}
\hline No. & Domain & Number of Items & Items \\
\hline 1. & The role of the English language teacher & 6 & $1-6$ \\
2. & The role of the students & 6 & $7-12$ \\
\hline 3. & The role of the curriculum & 6 & $13-18$ \\
\hline 4. & The role of the classroom environment & 6 & $19-24$ \\
\hline Total & & 24 & \\
\hline
\end{tabular}

\section{Instrument Reliability and Credibility}

The academic supervisor reviewed the instrument of the study at Al- Quds Open University, who recommended its validity after certain modifications, and the researcher got the questionnaire in its final form. As for the reliability of the instrument of the study, Cronbach's Alpha equation was used to extract the instrument's reliability. The total value was (82\%), and this percentage assured the possibility of using the instrument. The 
Tahani R. K. Bsharat \& Fariza Behak, The Influence of Social Media on Palestinians ...

researcher presented the questionnaire to the academic supervisor, who proved its credibility, so the researcher made these changes according to the supervisor's instructions.

\section{RESULTS AND DISCUSSION}

After collecting the data, those have been input to the computer to be treated using (SPSS) Statistical Packages for Social Science, and the following statistics were used. First were means and percentages, the second was standard and deviations, and the last statistics were T-test and One Way (ANOVA). In this section, the researcher surveys the results and the hypothesis of the study.

\section{Results}

The majority of the English language teachers' responses declared that the influence of social media on Palestinian secondary school's English writing skills during the COVID19 virus in the Jenin region has negative results from the English language teachers' questionnaire responses that means there is no effect at all. It is also described by all of the results of statistical data that there is no effect between the social media on Palestinian secondary school's English writing skills from teachers' perspective related to the gender, academic qualification, and years of experience variables. The complete descriptions of all the variables tested are as follow:

The influence of social media on Palestinian secondary schools English writing skills from teachers' perspectives in Jenin region related to the gender

The result related to the first hypothesis is there are no significant differences at ( $\alpha$ $=0.05$ ) about the influence of social media on Palestinian secondary schools' English writing skills from teachers' perspectives in the Jenin region related to the gender variable. The researcher used the T-test which the results presented in Table 5 below.

Table 5.

Results according to the gender variable for the English language teachers.

\begin{tabular}{|c|c|c|c|c|c|c|c|}
\hline \multirow{2}{*}{ No. } & \multirow{2}{*}{ Domains } & \multicolumn{2}{|l|}{ Male } & \multicolumn{2}{|l|}{ Female } & \multirow{2}{*}{ (T) } & \multirow{2}{*}{ SIG } \\
\hline & & $\mathbf{M}$ & S.D. & $\mathbf{M}$ & S.D. & & \\
\hline 1. & The role of the teacher & 4.8000 & .11180 & 4.4559 & .50956 & .523 & .005 \\
\hline 2. & The role of the students & 4.6500 & .41833 & 4.2059 & .55365 & .466 & .473 \\
\hline 3. & The role of the curriculum & 4.2400 & .32863 & 3.6824 & .54799 & .252 & .328 \\
\hline \multirow[t]{2}{*}{4.} & $\begin{array}{l}\text { The role of the classroom } \\
\text { environment }\end{array}$ & 3.0000 & .40825 & 3.0000 & .52705 & .000 & .460 \\
\hline & Respondents' total score & 4.17 & 0.318 & 3.83 & 0.534 & 1.82 & 0.31 \\
\hline
\end{tabular}

*Statistically significant of the (0.05) level.

Note: M stands for (Mean), S.D. stands for (Standard deviation), SIG stands for (Significant) 
Table 5 shows no significant differences at the $(\alpha=0.05)$ about the influence of social media on Palestinian secondary schools' English writing skills from teachers' perspectives in the Jenin region related to the gender variable at the whole domains at the total score. The significant level for ( $\mathrm{T}$ ) values was more than $(0.05)$. Consequently, the null hypothesis is accepted.

The influence of social media on Palestinian secondary schools English writing skills from teachers' perspectives in the Jenin region related to the academic qualification

Table (6) below shows the results related to the second hypothesis, which states that there are no significant differences at ( $\alpha=0.05$ ) about the influence of social media on Palestinian secondary schools' English writing skills from teachers' perspectives in the Jenin region related to the academic qualification variable. To examine this hypothesis, the researcher used the T-test. Table 6 shows the results.

Table 6.

Results according to the academic qualification variable.

\begin{tabular}{|c|c|c|c|c|c|c|c|}
\hline \multirow{2}{*}{ No. } & \multirow{2}{*}{ Domains } & \multicolumn{2}{|c|}{5 years or less } & \multicolumn{2}{|c|}{$\begin{array}{l}\text { More than } 5 \\
\text { years }\end{array}$} & \multirow{2}{*}{ (T) } & \multirow{2}{*}{ SIG } \\
\hline & & $\mathbf{M}$ & S.D. & $\mathbf{M}$ & S.D. & & \\
\hline 1. & The role of the teacher & 4.5341 & .47117 & 4.333. & .47117 & 2.581 & .005 \\
\hline 2. & The role of the students & 4.3068 & .55060 & 4.232 . & .55060 & 1.929 & .473 \\
\hline 3. & The role of the curriculum & 3.8091 & .55370 & 3.786. & .55370 & 2.814 & .328 \\
\hline \multirow[t]{2}{*}{4.} & $\begin{array}{l}\text { The role of the classroom } \\
\text { environment }\end{array}$ & 3.0000 & .49334 & 3.112 & .49334 & .000 & .460 \\
\hline & Respondents' total score & 3.985 & .37951 & 3.894 & .30517 & 2.862 & 0.3165 \\
\hline
\end{tabular}

Table 6 shows no significant differences at the $(\alpha=0.05)$ about the influence of social media on Palestinian secondary schools English writing skills from teachers' perspectives in the Jenin region related to the academic qualification variable at the domains $(1,2,3,4)$ and the total score. The significant level for (T) values was more than (0.05). Therefore, the null hypothesis is accepted.

The influence of social media on Palestinian secondary schools English writing skills from teachers' perspectives in the Jenin region related to the years of experience

The results related to the third hypothesis, which states that there are no significant differences at $(\alpha=0.05$ ) about the influence of social media on Palestinian secondary schools' English writing skills from teachers' perspectives in the Jenin region the years of experience variable. To examine this hypothesis, the researcher used the T-test. Tables (7) show the results. 
Table 7.

Results according to the years of experience variable.

\begin{tabular}{|c|c|c|c|c|c|c|c|}
\hline \multirow{2}{*}{ No. } & \multirow{2}{*}{ Domains } & \multicolumn{2}{|c|}{5 years or less } & \multicolumn{2}{|c|}{ More than 5 years } & \multirow{2}{*}{$(\mathrm{T})$} & \multirow{2}{*}{ SIG } \\
\hline & & $\mathbf{M}$ & S.D. & $\mathbf{M}$ & S.D. & & \\
\hline 1. & The role of the teacher & 4.8333 & .14434 & 4.4868 & .48929 & 2.478 & .052 \\
\hline 2. & The role of the students & 4.5833 & .72169 & 4.2632 & .53016 & .738 & .465 \\
\hline 3. & The role of the curriculum & 4.2000 & .60000 & 3.7474 & .53683 & 1.231 & .957 \\
\hline \multirow[t]{2}{*}{4.} & $\begin{array}{l}\text { The role of the classroom } \\
\text { environment }\end{array}$ & 3.0000 & .57735 & 3.0000 & .49690 & .000 & .653 \\
\hline & Respondents' total score & 4.15 & 0.51 & 4.15 & 0.51 & 0.86 & 0.53 \\
\hline
\end{tabular}

*Statistically significant of the (0.05) level.

There is no influence of social media on Palestinian secondary schools' English writing skills from teachers' perspectives in the Jenin region related to the years of experience variable at the whole domains and at the total score. The significant level for (T) values was more than (0.05). Consequently, the null hypothesis is accepted.

\section{DISCUSSION}

The majority of the English language teachers' responses declared that the influence of social media on Palestinian secondary school's English writing skills during the COVID19 virus in the Jenin region has negative results from the questionnaire responses of the English language teachers that means there is no effect at all. Besides, the results related to the first hypothesis showed that there are no significant differences at the ( $\alpha=0.05$ ) about the effect of social media on Palestinian secondary schools English writing proficiency from teachers perspectives in the Jenin region related to the gender variable at the whole domains and the total score. Also, the second hypothesis showed no significant differences at the ( $\alpha=0.05$ ) about the effect of social media on Palestinian secondary schools English writing proficiency from teachers' perspectives in the Jenin region related to the academic qualification variable four domains, and at the total score. Finally, the third hypothesis results showed no significant differences at ( $\alpha=0.05)$. It reflects that there is no effect of social media on Palestinian secondary schools' English writing proficiency from teachers' perspectives in the Jenin region related to the years of experience variable at the whole domains and at the total score.

On the other hand, the researchers mentioned in their studies (Evans, 2014; Lee et al., 2016; Menkhoff et al., 2015; Suthiwartnarueput \& Wasanasomsithi, 2012; Van den beemt et al., 2019; Vikneswaran \& Krish, 2016) that there are effects in influencing social media. This current study is existing research repeatedly focused on one aspect: social media in general in all the subjects' science and math. However, this current study focused on the English language. In these studies, they mentioned social media in general without 
paying attention to interrelatedness. Thus, this study was constructed on writing skills for English language from the English language teachers' point of view.

Some of the recommendations that can be offered after surveying and discussing the results to enhance students' are; 1 . Teachers should improve their skills in teaching English by using social media on the students' progress. 2. Teachers have to pay more attention and emphasize new and modern ways of using social media on the students' progress to enrich their experience. 3. Teachers should increase students' self-esteem by allowing them to participate more through using social media in classroom activities. 4. Teachers need to consider individual differences among students' when they try in various ways through using social media. 5. The Ministry of Education should train teachers on class management. It should create conditions that permit curriculum planning and create materials and develop teaching methods that focus on teaching English through social media on the students' progress.

\section{CONCLUSION}

As mentioned before, developing social media's influence on Palestinian secondary schools' English writing skills from teachers' perspectives is a significant issue in the learning process in general. To do that, improving teacher styles in teaching the English language must be the Ministry of Education's goal by holding programs, workshops, training courses, and making visits to foreign schools to enrich teachers' experiences. Besides, teachers can improve their social media use in teaching English by adapting new and modern procedures of using social media to their students' progress.

\section{REFERENCES}

Al-Sharawneh, I. (2014). Evaluation of Assessment Practices in English Writing for High School Palestinian Students: A Critical Study. Hebron: Hebron University.

Cole, M., Hibbert, D., \& Kehoe, E. (2013). Students' Perceptions of Using Twitter To Interact with the Instructor during Lectures for a Large-Enrollment Chemistry Course. Journal of Chemical Education, 90(5), 671-672. doi: 10.1021/ed3005825

Crook, C., Fisher, T., Graber, R., Harrison, C., Lewin, C., Logan, K., ... Sharples, M. (2008). Web 2.0 Technologies for Learning: The Current Landscape - Opportunities, Challenges and Tensions (pp. 1-72) [Research Report]. Nottingham: University of Nottingham.

Dickie, V., \& Meier, H. (2015). The Facebook Tutor: Networking Education. Ubiquitous Learning: An International Journal, 8(2), 15-20. doi: 10.18848/18359795/CGP/v08i02/40400

Dougherty, K., \& Andercheck, B. (2014). Using Facebook to Engage Learners in a Large Introductory Course. Teaching Sociology, 42, 95-104. doi: 10.1177/0092055X14521022 
Tahani R. K. Bsharat \& Fariza Behak, The Influence of Social Media on Palestinians ...

Evans, C. (2014). Twitter for Teaching: Can Social Media be Used to Enhance the Process of Learning? British Journal of Educational Technology, 45(5), 902-915. doi: https://doi.org/10.1111/bjet.12099

Goktalay, B. S. (2013). Challenges Facing Higher Education: Faculty's Concerns about Technologies of Social Media. Int. J. of Continuing Engineering Education and LifeLong Learning, 23(1), 67-90. doi: 10.1504/IJCEELL.2013.051767

Kamalodeen, V., \& Jameson-Charles, M. (2016). A Mixed Methods Research Approach to Exploring Teacher Participation in an Online Social Networking Website. The International Journal of Qualitative Methods, 15, 1-14. doi: $10.1177 / 1609406915624578$

Kavaliauskienè, G. (2010). Skills of Reading, Writing and Translating in English for Specific Purposes. The Buckingham Journal of Language and Linguistics, 3, 11-23. doi: 10.5750/bjll.v3i0.21

Khalil, A. (2002). Analysis of Errors made by Arab EFL learners. Bethlehem University, Palestine.

Kukulska-Hulme, A. (2012). Language Learning Defined by Time and Place: A Framework for Next Generation Designs. In J. E. Díaz-Vera (Ed.), Left to My Own Devices: Learner Autonomy and Mobile Assisted Language Learning (Vol. 6, pp. 1-13). Bingley, UK: Emerald Group Publishing Limited. Retrieved from http://www.emeraldinsight.com/products/books/series.htm?id=2041-272x

Lee, J., Koo, Y., \& Kim, M. (2016). Enhancing Problem Solving Skills in Science Education with Social Media and an e-collaboration Tool. The New Educational Review, 43(1), 248-258. doi: 10.15804/tner.2016.43.1.21

Margaryan, A., \& Littlejohn, A. (2011). Are Digital Natives a Myth or Reality?: Students' Use of Technologies for Learning. Computers \& Education, 56(2), 429-440. doi: 10.1016/j.compedu.2010.09.004

Menkhoff, T., Chay, Y. W., Bengtsson, M. L., Woodard, C. J., \& Gan, B. (2015). Incorporating Microblogging ("Tweeting") in Higher Education: Lessons Learnt in a Knowledge Management Course. Computers in Human Behavior, 51, 1295-1302. doi: 10.1016/j.chb.2014.11.063

Millrood, R. P. (2001). Modular Course in ELT Methodology. Moscow: Drofa.

Minocha, S. (2009). A Case Study-Based Investigation of Students' Experiences with Social Software. Review of Hypermedia and Multimedia, 15(3), 245-265. doi: $10.1080 / 13614560903494320$

Rinaldo, S., Tapp, S., \& Laverie, D. (2011). Learning by Tweeting: Using Twitter as a Pedagogical Tool. Journal of Marketing Education - J Market Educ, 33(2), 193-203. doi: $10.1177 / 0273475311410852$

Sobaih, A. E., Moustafa, M., Ghandforoush, P., \& Khan, M. (2016). To Use or Not to Use? Social Media in Higher Education in Developing Countries. Computers in Human Behavior, 58, 296-305. doi: 10.1016/j.chb.2016.01.002

Solis, B. (2008). Coining the Statusphere: The Social Web's Next Big Thing.

Suthiwartnarueput, T., \& Wasanasomsithi, P. (2012). Effects of Using Facebook as a Medium for Discussions of English Grammar and Writing of Low-Intermediate EFL Students. Electronic Journal of Foreign Language Teaching, 9(2), 194-214. 
Toivo, S. (2012). Social Media-The New Power of Political Influence. Brussels: Centre for European Studies.

Van den beemt, A., Thurlings, M., \& Willems, M. (2019). Towards An Understanding of Social Media Use in the Classroom: A Literature Review. Technology, Pedagogy and Education, 29(8), 1-21. doi: 10.1080/1475939X.2019.1695657

Vikneswaran, T., \& Krish, P. (2016). Utilising Social Networking Sites to Improve Writing: A Case Study with Chinese Students in Malaysia. Technology, Pedagogy and Education, 25(3), 287-300. doi: 10.1080/1475939X.2015.1030441

Wang, X. (2013). Why Students Choose STEM Majors: Motivation, High School Learning, and Postsecondary Context of Support. American Educational Research Journal, 50(5), 1081-1121. doi: 10.3102/0002831213488622

Zepke, N., \& Leach, L. (2010). Improving Student Engagement: Ten Proposals for Action. Active Learning in Higher Education, 11(3), 167-177. doi: $10.1177 / 1469787410379680$ 
Appendix(A) The questionnaire for English language teachers.

\section{Questionnaire}

Dear teachers:

This study aims to investigate ( The Influence of Social Media on Palestinian Secondary Schools English Writing Skills from English Teachers Perspectives in Jenin Region).

Your answers will be secret, taking in to consideration that all the information you give will be used for scientific research only.

The researcher: Tahani R. K. Bsharat.

Note: this questionnaire has two sections:

*Section one: the personal information, please put the mark $(x)$ in the suitable place.

*Section two: this section contains (24) items, please put the mark (x) in the place suits your case. 


\section{Section One:}

\section{The personal information}

1- Gender:

1. Male

2. Female

2- Academic Qualification:

1. Bachelor or less

1.

2. Master or more

3- Years of Experience

1. 5 years or less

2. More than 5 years
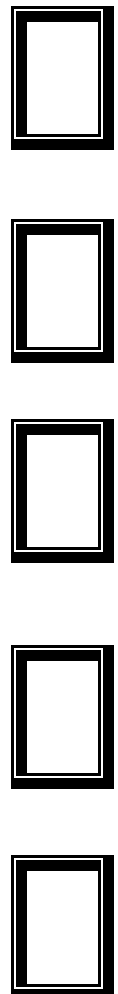


\section{Section Two:}

please put the mark (x) in the place suits your case.

\begin{tabular}{|c|c|c|c|c|c|c|}
\hline No. & Paragraph & Agree & $\begin{array}{l}\text { Strongly } \\
\text { agree }\end{array}$ & Neutral & Disagree & $\begin{array}{l}\text { Strongly } \\
\text { disagree }\end{array}$ \\
\hline 1- & $\begin{array}{l}\text { Using social media by the } \\
\text { teacher affects the secondary } \\
\text { students English writing skill. }\end{array}$ & & & & & \\
\hline $2-$ & $\begin{array}{l}\text { English teacher has the } \\
\text { appropriate styles in using } \\
\text { social media to enhance the } \\
\text { secondary students English } \\
\text { writing proficiency. }\end{array}$ & & & & & \\
\hline 3- & $\begin{array}{l}\text { Mastering using social media by } \\
\text { the teacher contributes in } \\
\text { teaching secondary students } \\
\text { English writing skill. }\end{array}$ & & & & & \\
\hline 4- & $\begin{array}{l}\text { Using feedback by the teacher } \\
\text { through using social media } \\
\text { confirms teaching secondary } \\
\text { students English writing } \\
\text { proficiency. }\end{array}$ & & & & & \\
\hline 5- & $\begin{array}{l}\text { Using social media has a } \\
\text { positive impact on the } \\
\text { secondary students English } \\
\text { writing skill. }\end{array}$ & & & & & \\
\hline 6- & $\begin{array}{l}\text { English teacher encourages } \\
\text { using social media to support } \\
\text { secondary students English } \\
\text { writing skill. }\end{array}$ & & & & & \\
\hline 7- & $\begin{array}{l}\text { Social media helps to link } \\
\text { English language teacher with } \\
\text { secondary students at home. }\end{array}$ & & & & & \\
\hline 8- & $\begin{array}{l}\text { Secondary students tend to use } \\
\text { social media which affects } \\
\text { learning English writing skill. }\end{array}$ & & & & & \\
\hline 9- & $\begin{array}{l}\text { Using social media by } \\
\text { secondary students as a } \\
\text { modern way which have the } \\
\text { elements of excitement to } \\
\text { support their English writing } \\
\text { skills. }\end{array}$ & & & & & \\
\hline
\end{tabular}




\begin{tabular}{|c|c|c|c|c|c|c|}
\hline 10- & $\begin{array}{l}\text { Low accumulative achievement } \\
\text { for secondary students English } \\
\text { writing affects using social } \\
\text { media. }\end{array}$ & & & & & \\
\hline 11- & $\begin{array}{l}\text { Social media motivates } \\
\text { secondary students interest to } \\
\text { use English writing skill. }\end{array}$ & & & & & \\
\hline 12- & $\begin{array}{l}\text { Secondary boys using social } \\
\text { media more than secondary } \\
\text { girls to support their English } \\
\text { writing skills. }\end{array}$ & & & & & \\
\hline 13- & $\begin{array}{l}\text { Social media enriches the } \\
\text { curriculum and stimulates } \\
\text { secondary students } \\
\text { for English writing in the most } \\
\text { effective and active way. }\end{array}$ & & & & & \\
\hline No. & Paragraph & Agree & $\begin{array}{l}\text { Strongly } \\
\text { agree }\end{array}$ & Neutral & Disagree & $\begin{array}{l}\text { Strongly } \\
\text { disagree }\end{array}$ \\
\hline 14- & $\begin{array}{l}\text { Linking the curriculum with } \\
\text { social media increases the } \\
\text { ability of secondary students } \\
\text { English writing. }\end{array}$ & & & & & \\
\hline 15- & $\begin{array}{l}\text { Curriculum has a positive effect } \\
\text { on secondary students English } \\
\text { dictation writing through using } \\
\text { social media. }\end{array}$ & & & & & \\
\hline 16- & $\begin{array}{l}\text { Curriculum does not support } \\
\text { using English language teachers } \\
\text { of social media in teaching their } \\
\text { secondary students English } \\
\text { writing skill. }\end{array}$ & & & & & \\
\hline 17- & $\begin{array}{l}\text { Curriculum affects positively in } \\
\text { using English language teachers } \\
\text { of social media for teaching } \\
\text { their secondary students } \\
\text { English writing skill. }\end{array}$ & & & & & \\
\hline 18- & $\begin{array}{l}\text { Curriculum gives secondary } \\
\text { students the chance to display } \\
\text { and edit their English writing } \\
\text { easily through using social } \\
\text { media. }\end{array}$ & & & & & \\
\hline
\end{tabular}




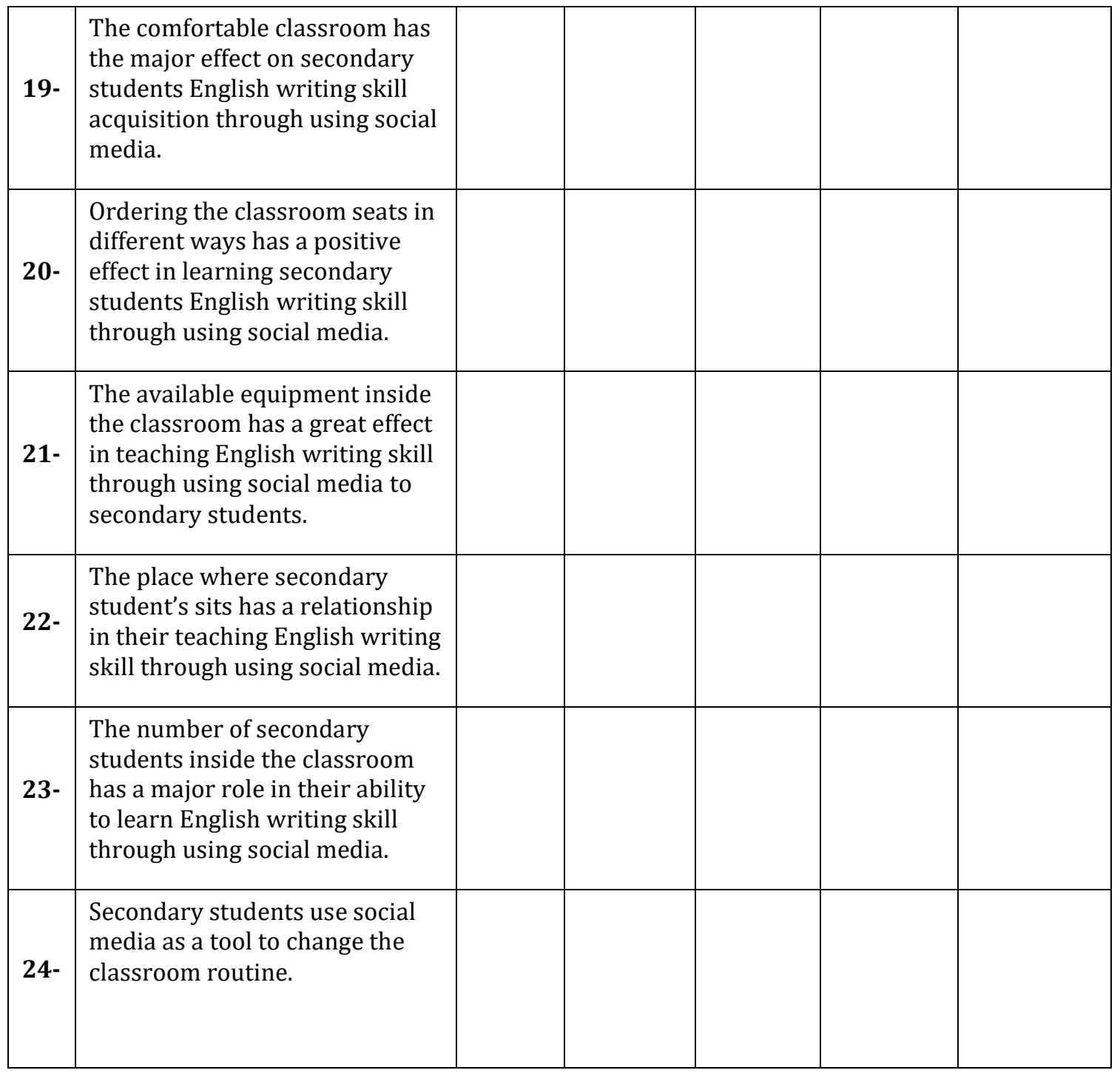

Thank you for your contribution 